\title{
How Protein Kinase C Activation Protects Nerve Cells from Oxidative Stress-Induced Cell Death
}

\author{
Pamela Maher \\ Department of Cell Biology, The Scripps Research Institute, La Jolla, California 92037
}

Oxidative stress is implicated in the nerve cell death that occurs in a variety of neurological disorders, and the loss of protein kinase $\mathrm{C}(\mathrm{PKC})$ activity has been coupled to the severity of the damage. The functional relationship between stress, PKC, and cell death is, however, unknown. Using an immortalized hippocampal cell line that is particularly sensitive to oxidative stress, I show that activation of PKC by the phorbol ester tetradecanoylphorbol acetate (TPA) inhibits cell death via the stimulation of a complex protein phosphorylation pathway. TPA treatment leads to the rapid activation of extracellular signalregulated kinase (ERK) and c-Jun $\mathrm{NH} 2$-terminal kinase (JNK), the inactivation of p38 mitogen-activated protein kinase (MAPK), and the downregulation of PKC $\delta$. Inhibition of either
ERK or JNK activation blocks TPA-mediated protection, whereas p38 MAPK and PKC $\delta$ inhibitors block stress-induced nerve cell death. Both p38 MAPK inactivation and JNK activation appear to be downstream of ERK because an agent that blocks ERK activation also blocks the modulation of these other MAP kinase family members by TPA treatment. Thus, the protection from oxidative stress afforded nerve cells by PKC activity requires the combined modulation of multiple enzyme pathways and suggests why the loss of PKC activity contributes to nerve cell death.

Key words: oxidative stress; programmed cell death; MAP kinases; protein kinase $C$; oxidative glutamate toxicity; reactive oxygen species
Although programmed cell death (PCD) plays an important role in the normal development of the nervous system, in adults, PCD is associated with the neuronal cell loss in neurodegenerative disease and trauma (Rubin, 1997). In all of these cases, PCD has been linked to oxidative stress and the production of reactive oxygen species (ROS) (Ames et al., 1993; Coyle and Puttfarcken, 1993; Beal, 1995; Rubin, 1997). One potential mechanism for the generation of ROS in the CNS is via the excitatory amino acid glutamate. Two pathways for glutamate toxicity have been described: excitotoxicity (Olney, 1969), which occurs through activation of ionotropic glutamate receptors, and oxidative glutamate toxicity (Murphy et al., 1989), which is mediated via a series of disturbances to the redox homeostasis of the cell. In the latter case, glutamate blocks cystine uptake via the inhibition of the glutamate/cystine antiporter, resulting in decreases in intracellular cysteine and glutathione (GSH), which can eventually lead to cell death (Murphy et al., 1989). The $\mathrm{IC}_{50}$ for inhibition of cystine uptake by extracellular glutamate is $50 \mu \mathrm{M}$ (Sagara and Schubert, 1998), well within the range attainable in the damaged nervous system (Newcomb et al., 1997; McAdoo et al., 1999). A critical role of $\mathrm{GSH}$ in protecting neuronal cells from PCD has been suggested by a number of in vitro and in vivo studies (for review, see Schulz et al., 2000). For instance, in Parkinson's disease patients, there is an early and specific decrease in GSH that precedes cell death. Similarly, GSH falls during ischemia (Koroshetz and Moskowitz, 1996). Thus, the early drop in cellular GSH

Received Oct. 9, 2000; Revised Dec. 22, 2000; accepted Jan 18, 2001.

This work was supported by the National Institutes of Health Grant NS28121. I thank Dr. David Schubert for the primary cortical neurons, as well as helpful discussions and critical reading of this manuscript, and Lori Huska for help in preparing the figures.

Correspondence should be addressed to Pamela Maher, Department of Cell Biology, The Scripps Research Institute, 10550 North Torrey Pines Road, La Jolla, CA 92037. E-mail: pmaher@scripps.edu.

Copyright (C) 2001 Society for Neuroscience 0270-6474/01/212929-10\$15.00/0 levels seen in oxidative glutamate toxicity is very similar to changes seen in vivo in neuronal cells responding to both acute and chronic injury.

In addition to decreases in $\mathrm{GSH}$, the loss of protein kinase $\mathrm{C}$ (PKC) activity is an essential element in the process of cell death in neurons exposed to oxidative stress, and a rapid decline in PKC activity is a prognostic feature of lethal damage to neurons after both ischemia in vivo and hypoxic and excitotoxic insults in vitro (Durkin et al., 1997 and references therein). However, why the maintenance of PKC activity leads to the protection of nerve cells from oxidative stress-induced cell death was unclear.

HT22 cells are a hippocampal cell line that lacks ionotropic glutamate receptors but is sensitive to glutamate-induced cell death via the oxidative pathway (Maher and Davis, 1996; Li et al., 1997b). The form of PCD seen in this model of oxidative stress has many of the characteristics of PCD seen in other systems (Tan et al., 1998a,b). A colleague and I found that activation of PKC by the phorbol ester tetradecanoylphorbol acetate (TPA) blocks oxidative glutamate toxicity in both the HT22 cells and primary cultures of cortical neurons (Davis and Maher, 1994). This report describes the pathways involved in PKC-mediated protection of nerve cells from oxidative stress-induced death. The complexity of this process suggests why studies with PKC inhibitors or activators have at times yielded contradictory results.

\section{MATERIALS AND METHODS}

Materials. PD98059 was obtained from Biomol (Plymouth Meeting, PA) and solubilized in DMSO. PD184352, SB202190, SB203580, SB202474, $\mathrm{G}_{\mathrm{o}} 6983$, and $\mathrm{R}_{\mathrm{o}} 318220$ were obtained from Calbiochem (La Jolla, CA) and solubilized in DMSO. Other chemicals and inhibitors were from Sigma (St. Louis, MO) or Research Biochemicals (Natick, MA). The dominant negative-c-Jun NH2-terminal kinase (DN-JNK) construct was obtained from G. Sanna and R. Ulevitch at The Scripps Research Institute (Sanna et al., 1998).

HT22 cell culture and viability assays. HT-4 cells, a mouse hippocampal cell line immortalized with a temperature-sensitive SV-40 T-antigen, 
were obtained from B. H. Morimoto and D. E. Koshland (University of California, Berkeley, CA) (Morimoto and Koshland, 1990) and subcloned. The HT-22 clone was the most sensitive to glutamate of the 25 clones tested and was used in the experiments described herein. The HT-22 clone was characterized in detail with respect to ionotropic glutamate receptors and found to have none (Maher and Davis, 1996). Cells were maintained at $37^{\circ} \mathrm{C}$ in DMEM-10\% fetal calf serum and passaged by trypsinization. Cell viability was routinely assayed at $37^{\circ} \mathrm{C}$ using the MTT assay (Hansen et al., 1989). For this assay, cells were plated into 96 -well plates at $5 \times 10^{3}$ cells per well in complete medium, and $24 \mathrm{hr}$ later the experimental agents were added. The ability of the cells to reduce MTT was assayed $24 \mathrm{hr}$ after the addition of the experimental agents, exactly as described previously (Davis and Maher, 1994). Controls using wells without cells and cells without glutamate were used to determine the effects of agents on the assay chemistry or cell viability, respectively. In all cases, the cells were examined under phase-contrast microscopy before the addition of MTT to visually assess the degree of cell death. Similar results were obtained using either a colony-forming assay (Cook and Mitchell, 1989) or a lactate dehydrogenase release assay.

Primary cortical cultures and viability studies. Primary cortical neurons were prepared from embryonic day 17 rats as described previously ( $\mathrm{Li}$ et al., 1997b) and maintained in minimal essential medium supplemented with $30 \mathrm{~mm}$ glucose, $2 \mathrm{~mm}$ glutamine, $1 \mathrm{~mm}$ pyruvate, and $10 \%$ fetal calf serum. Cell viability was assayed at $37^{\circ} \mathrm{C}$ using the MTT assay. For this assay, cells were plated on poly-L-lysine-coated 96-well dishes at $5 \times 10^{4}$ cells per well in growth medium, and $24 \mathrm{hr}$ later the experimental agents were added. The ability of the cells to reduce MTT was assayed $24 \mathrm{hr}$ after the addition of the experimental agents. Controls using wells without cells and cells without glutamate were used to determine the effects of agents on the assay chemistry or cell viability, respectively.

SDS-PAGE and immunoblotting. Proteins were separated on $10 \%$ SDS-polyacrylamide gels and transferred to nitrocellulose. Transfers were blocked for $2 \mathrm{hr}$ at room temperature with $5 \%$ nonfat milk in TBS $-0.1 \%$ Tween 20 and then incubated overnight at $4{ }^{\circ} \mathrm{C}$ in the primary antibody diluted in 5\% BSA in TBS- $0.05 \%$ Tween 20 . The primary antibodies used were as follows: phospho-specific p38 mitogen-activated protein kinase (MAPK) antibody (1:1000; catalog \#9211), phosphospecific MAPK antibody (1:1000; catalog \#9101), phospho-specific JNK/ stress-activated protein kinase (SAPK) antibody (1:1000; catalog \#9251), and JNK/SAPK antibody (1:1000; catalog \#9252) from New England Biolabs (Beverly, MA); p38 MAP kinase antibody (1:1000; catalog \#sc728) from Santa Cruz Biotechnology (Santa Cruz, CA); and pan extracellular signal-regulated kinase (ERK) antibody (1:5000) and all of the PKC antibodies from Transduction Laboratories (Lexington, KY). The transfers were rinsed with TBS- $0.05 \%$ Tween 20 and incubated for $1 \mathrm{hr}$ at room temperature in horseradish peroxidase-goat anti-rabbit or goat anti-mouse (Bio-Rad, Hercules, CA) diluted 1:5000 in 5\% nonfat milk in TBS- $-0.1 \%$ Tween 20 . The immunoblots were developed with the Super Signal reagent (Pierce, Rockford, IL). Autoradiograms were scanned using a ScanJet 4C/T scanner (Hewlett Packard), and the labeled bands were quantified using NIH Image (version 1.61).

MAPK-activated protein kinase-2. Cells in $60 \mathrm{~mm}$ dishes were solubilized in $500 \mu \mathrm{l}$ of $1 \%$ Triton X-100 in $50 \mathrm{~mm}$ Tris, pH 7.5, 1 mm EDTA, $1 \mathrm{~mm} \mathrm{Na}_{3} \mathrm{VO}_{4}, 0.1 \%$ 2-mercaptoethanol, $5 \mathrm{~mm}$ sodium pyrophosphate, 10 $\mathrm{mM}$ sodium glycerophosphate, $50 \mathrm{~mm} \mathrm{NaF}, 0.1 \mathrm{~mm}$ PMSF, $1 \mu \mathrm{g} / \mathrm{ml}$ aprotinin, and $1 \mu \mathrm{g} / \mathrm{ml}$ leupeptin. MAPK-activated protein (MAPKAP) kinase-2 in the supernatants was collected with sheep anti-rabbit MAPKAP kinase-2 (Upstate Biotechnology, Lake Placid, NY) preabsorbed to protein G-Sepharose. The immunoprecipitates were washed once with solubilization buffer containing $500 \mathrm{~mm} \mathrm{NaCl}$, once with solubilization buffer, and once with kinase assay buffer and resuspended in $30 \mu \mathrm{l}$ of kinase assay buffer (in mM: 20 MOPS, $\mathrm{pH} 7.2,25$ sodium glycerophosphate, 5 EGTA, $1 \mathrm{Na}_{3} \mathrm{VO}_{4}$, and 1 DTT) containing $25 \mathrm{~mm}$ $\mathrm{MgCl}_{2}, 150 \mu \mathrm{M}$ ATP, $10 \mu \mathrm{Ci} /$ assay $\left[\gamma^{-}{ }^{32} \mathrm{P}\right] \mathrm{ATP}$ (ICN Biochemicals, Costa Mesa, CA), and $62.5 \mu \mathrm{M}$ MAPKAP kinase-2 substrate peptide (Upstate Biotechnology). After incubation at $30^{\circ} \mathrm{C}$ for $30 \mathrm{~min}$, the protein G-Sepharose beads were pelleted, and the supernatants were transferred to P81 phosphocellulose paper disks. The disks were washed three times with $1 \%$ phosphoric acid and once with $\mathrm{H}_{2} \mathrm{O}$ and counted in a liquid scintillation counter.

Transfection assays. Cells were transfected with $0.5 \mu \mathrm{g}$ of pcDNA3.1/ lac $Z$ and $0.5 \mu \mathrm{g}$ of either empty vector (pcDNA3.1) or DN-JNK using Effectene (Qiagen, Hilden, Germany). Twenty-four hours after transfection, the cells were treated with glutamate and/or TPA for $24 \mathrm{hr}$, after which they were fixed and stained with 5-bromo-4-chloro-3-indolyl- $\beta$-D-

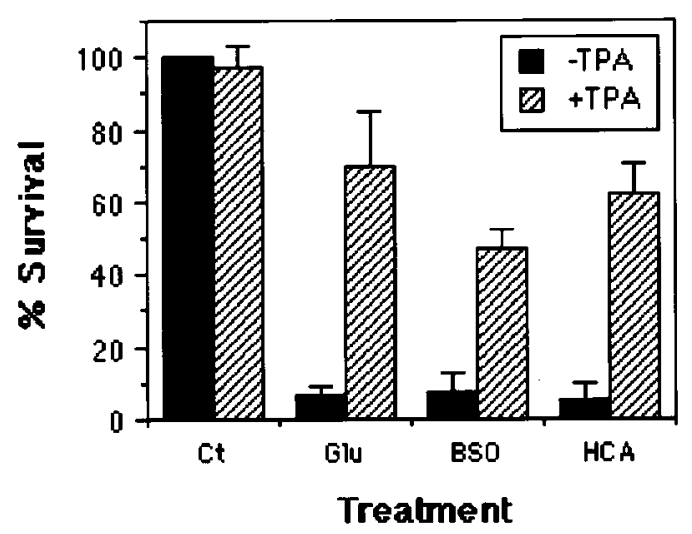

Figure 1. TPA protects HT22 cells from multiple forms of oxidative stress. HT22 cells were untreated or treated with $5 \mathrm{~mm}$ glutamate, $1 \mathrm{~mm}$ $\mathrm{BSO}$, or $2.5 \mathrm{~mm} \mathrm{HCA}$ in the absence or presence of $100 \mathrm{ng} / \mathrm{ml}$ TPA. Percent survival was measured after $24 \mathrm{hr}$ by the MTT method. The data represent the mean $\pm \mathrm{SD}$ of three independent experiments, with each point done in quadruplicate.

galactopyranoside (X-gal) (Ausubel et al., 1999), and the number of blue cells per $35 \mathrm{~mm}$ dish was determined microscopically.

ROS measurement. ROS production was detected using the dye dichlorofluorescin diacetate (DCF) as described after a $10 \mathrm{hr}$ treatment with glutamate (Tan et al., 1998a). A $10 \mathrm{hr}$ treatment with glutamate was shown previously to result in maximal ROS production (Tan et al., 1998a). DCF was added to the cells during dissociation with pancreatin. After incubation for $10 \mathrm{~min}$ at $37^{\circ} \mathrm{C}$, the cells were washed and filtered. Propidium iodide was used to gate for live cells. Data were collected with a FACScan cell scanner using the data acquisition program CELLQuest (Becton Dickinson, Cockeysville, MD). DCF data were collected with an excitation wavelength of $475 \mathrm{~nm}$ and an emission wavelength of $525 \mathrm{~nm}$. Ten thousand live cells, as determined by the lack of propidium iodide fluorescence, were analyzed per sample. DCF data were plotted as histograms, and the sample values were divided by the control value to yield the ratiometric increase in DCF fluorescence for each treatment.

\section{RESULTS}

Previously, a colleague and I showed that the activation of PKC by the phorbol ester TPA blocks oxidative glutamate toxicity in both the HT22 cells and primary cultures of cortical neurons (Davis and Maher, 1994). However, neither the generality of this protection nor the mechanisms underlying it were determined. The studies described below were performed to answer these questions. TPA not only protects the HT22 cells from oxidative glutamate toxicity, but it also blocks cell death induced by either glutathione depletion using the glutathione synthesis inhibitor buthionine sulfoximine (BSO) or by the inhibition of cystine uptake using homocysteic acid (HCA) (Fig. 1). Thus, PKC activation protects cells from various forms of oxidative stress, strongly suggesting that additional investigation into its mechanism of action is warranted.

When HT22 cells or cortical neurons are exposed to glutamate, there is a rapid decline in intracellular GSH, followed by a large increase in the level of peroxides. Previous studies indicated that, although TPA had no effect on this initial drop in GSH levels, it did need to be added to the cells within $4 \mathrm{hr}$ after the addition of glutamate to inhibit cell death (Davis and Maher, 1994), suggesting that TPA blocked a relatively early step in the pathway leading to cell death. Thus, it was of interest to determine whether it blocked the increase in ROS induced by glutamate treatment. Surprisingly, TPA had no effect on the increase in ROS production seen after the addition of glutamate to the cells (data not shown), indicating that the protective effect of TPA was 
A.

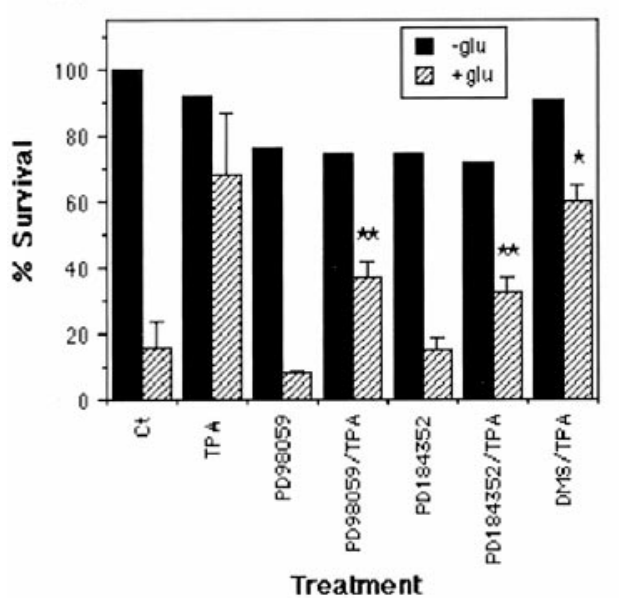

C.

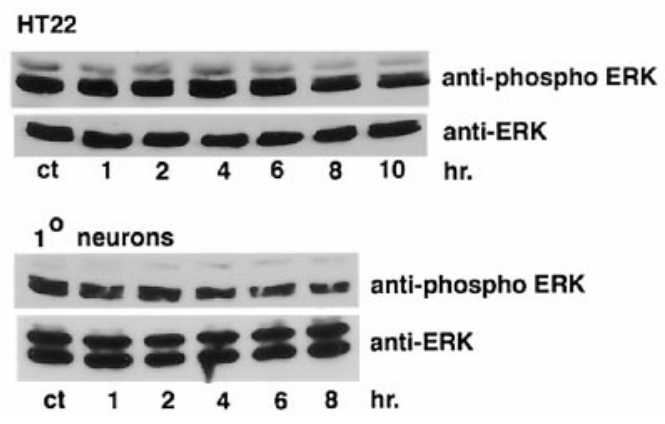

B.

Primary Neurons

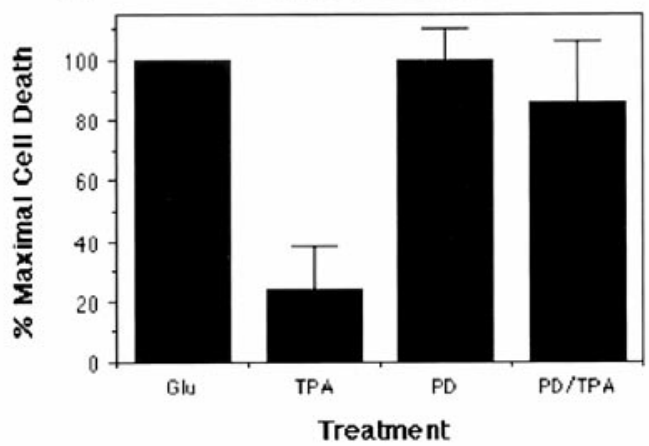

D.

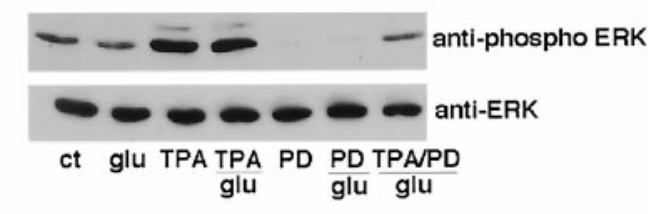

Figure 2. ERK activity is required for TPA-mediated protection. $A$, HT22 cells were treated with 5 mm glutamate alone $(C t)$ or in the presence of 100 ng/ml TPA (TPA), $50 \mu \mathrm{M}$ PD98059 (PD98059), TPA plus $50 \mu \mathrm{M}$ PD98059 (PD98059/TPA), $5 \mu \mathrm{M}$ PD184352 (PD184352), TPA plus $5 \mu$ M PD184352 $(P D 184352 / T P A)$, or TPA plus $1 \mu \mathrm{M}$ dimethyl sphingosine $(D M S / T P A)$. Percent survival was measured after 24 hr by the MTT method. The data represent the mean $\pm \mathrm{SD}$ of three to five independent experiments, with each point done in quadruplicate. * indicates not significantly different from glutamate ( glu $)$ plus TPA (Student's $t$ test); ${ }^{* *}$ indicates significantly different from cells treated with glutamate plus dimethyl sphingosine plus TPA $(p<$ 0.0001; Student's $t$ test) and cells treated with glutamate plus TPA $(p<0.005$; Student's $t$ test). B, Primary cortical neurons were treated with 5 mM glutamate alone $(G l u)$ or in the presence of $100 \mathrm{ng} / \mathrm{ml}$ TPA $(T P A), 50 \mu \mathrm{M}$ PD98059 (PD), or TPA plus $50 \mu \mathrm{M}$ PD98059 (PD/TPA). Cell survival was measured after $24 \mathrm{hr}$ by the MTT method, and the results are presented as the percentage of the cell death seen in the presence of glutamate ( $30-40 \%)$, which is arbitrarily set at $100 \%$. PD98059 $(50 \mu \mathrm{M})$ alone had little effect on cell survival $(91.5 \pm 5.2 \%$ of the cells in untreated controls). The data represent the mean \pm SD of a single experiment, with each point done in quadruplicate. Similar results were obtained in two independent experiments. $C$, Time course showing the effect of glutamate on ERK activity in HT22 cells and primary cortical neurons. Cells were untreated ( $c t$ ) or treated for up to $10 \mathrm{hr}$ with $5 \mathrm{~mm}$ glutamate. The cells were scraped into sample buffer and analyzed by SDS-PAGE and immunoblotting with an antibody specific for phosphorylated ERKs (anti-phospho ERK) and an antibody that detects phosphorylated and unphosphorylated ERKs (anti-ERK). Similar results were obtained in three (HT22 cells) and two (primary neurons) independent experiments. $D$, HT22 cells were untreated ( $c t$ ) or treated with 5 mM glutamate ( glu), $100 \mathrm{ng} / \mathrm{ml}$ TPA (TPA), glutamate plus TPA (TPA/glu), $50 \mu \mathrm{M}$ PD98059 (PD), glutamate plus PD98059 (PD/glu), or glutamate plus TPA and PD98059 (TPA/PD/glu) for $8 \mathrm{hr}$. The cells were scraped into sample buffer and analyzed by SDS-PAGE and immunoblotting with an antibody specific for phosphorylated ERKs (anti-phospho ERK) and an antibody that detects phosphorylated and unphosphorylated ERKs (anti-ERK). Similar results were obtained in five independent experiments.

mediated via the induction of one or more pathways whose activity could counteract the effects of ROS production rather than via a direct effect on ROS production itself.

To further characterize the role of PKC in neuronal cell death, I focused on signaling pathways that had been shown previously to be activated by PKC and were implicated in cell death in other systems. One of these pathways involves the ERKs, whose activation has been implicated in the protection from cell death in a variety of different systems (Xia et al., 1995; Guvillier et al., 1996; Wang et al., 1998; Singer et al., 1999). Accordingly, I first examined the effect of a specific inhibitor of ERK activation, the ERK-specific mitogen-activated protein kinase kinase (MEK) inhibitor PD98059 (Cohen, 1998) on the ability of TPA to protect HT22 cells from oxidative glutamate toxicity. As shown in Figure $2 A$, PD98059 significantly reduced the protection from cell death afforded by treatment with TPA, whereas PD98059 alone had little effect on glutamate-induced cell death. The negative effect of MEK inhibition on the TPA-mediated protection from oxidative glutamate toxicity was substantiated with a new, structurally and functionally distinct MEK inhibitor, PD184352 (SeboltLeopold et al., 1999) (Fig. 2A). Similar results were obtained with PD98059 and primary cortical neurons (Fig. 2B). Consistent with these data, ERK activity, as assayed by immunoblotting with an antibody against the phosphorylated, and thereby activated, form of ERK, was relatively high in untreated HT22 cells and decreased slightly by $8 \mathrm{hr}$ of glutamate treatment (Fig. 2C). The viability of the HT22 cells also remains constant for $8 \mathrm{hr}$ in the presence of glutamate but falls sharply after $10 \mathrm{hr}$ of glutamate treatment (Li et al., 1997a). A slight decrease in ERK activation after $8 \mathrm{hr}$ of glutamate treatment was also seen with the primary cortical neurons (Fig. 2C). In contrast to these data are two studies in which glutamate treatment stimulated ERK activation 
in the HT22 cells (Satoh et al., 2000; Stanciu et al., 2000). This difference may be attributable to differences in the responsiveness of the ERK pathway in HT22 cells cultured in different laboratories or to the effects of cell density on ERK activation. All of my biochemical studies were performed on cells cultured at the same density as that used in the cell death assays. Cells cultured at higher densities do not die and do not show the same responses in biochemical assays.

To provide additional evidence that at least one of the effects of TPA involves ERK activation, I assayed ERK activation after TPA treatment in the presence and absence of glutamate and/or PD98059. Figure 2D demonstrates that not only did TPA induce a twofold increase in ERK activation, but it maintained this increase in the presence of glutamate. Glutamate treatment itself caused a 20-30\% decrease in ERK activity (Fig. 2C,D). PD98059 greatly reduced the basal level of activated ERK and also reduced by $60-70 \%$ the increase in ERK activation brought about by TPA treatment in the presence of glutamate (Fig. 2B). Similar results were seen with PD184352 (data not shown). However, dimethyl sphingosine, an inhibitor of sphingosine kinase, had no effect on the protection provided by TPA (Fig. $2 A$ ), indicating that, unlike a previous study (Guvillier et al., 1996), PKC activation did not lead to ERK activation through a pathway involving sphingosine1-phosphate.

Because some studies (Xia et al., 1995; Guvillier et al., 1996) have suggested that protection from cell death is dependent on high levels of ERK activity relative to the levels of both JNK and p38 MAP kinase activity, I investigated the effects of both glutamate and TPA on the activities of these other two MAPK family members using antibodies to the activated forms of the enzymes. Glutamate alone increased p38 MAPK activation severalfold (Fig. 3A), whereas TPA decreased p38 MAPK activation by $30-60 \%$ (Fig. $3 A$ ) and blocked the increase in activation induced by glutamate treatment (Fig. $3 A$ ). These results were confirmed in an in vitro kinase assay in which the activity of a specific and direct substrate of p38 MAPK, MAPKAP kinase-2, was determined and used as an additional measure of p38 MAPK activation (Fig. $3 C$ ). In contrast to these results with p38 MAPK, glutamate alone had no effect on JNK activation (Fig. $3 A$ ), whereas TPA greatly increased $\mathrm{JNK}$ activation both alone and in the presence of glutamate (Fig. 3A). Both the TPA-mediated increase in JNK activation and the decrease in p38 MAPK activation were completely blocked by PD98059 (Fig. 3B), indicating that the activation of both of these kinases are regulated by ERKs. However, it is unlikely that the activation of JNK is dependent on the inactivation of p38 MAPK because p38 MAPK inhibitors did not stimulate JNK activation (data not shown).

One mechanism whereby ERKs could effect the downregulation of p38 MAPK activity is through the activation of specific phosphatases belonging to the MAP kinase phosphatase (MKP) family (for review, see Haneda et al., 1998; Keyse, 1999). To determine whether the downregulation of p38 MAPK activity by TPA in the HT22 cells is mediated by phosphatases, I tested the effect of sodium orthovanadate, which was shown to inhibit several different MKPs (Misra-Press et al., 1995; Tanoue et al., 1999), as well as protein tyrosine phosphatases. As shown in Figure $4 A$, sodium orthovanadate alone stimulates ERK activity, and it slightly enhances the activation of ERKs induced by TPA. Furthermore, sodium orthovanadate not only stimulates basal p38 MAPK activity but it also inhibits the TPA-induced decrease in p38 MAPK activity. These results were confirmed in the in vitro kinase assay for MAPKAP kinase-2 activation (Fig. 4B) and are
A.

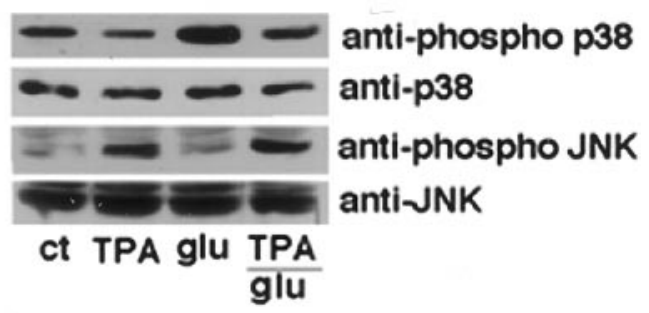

B.
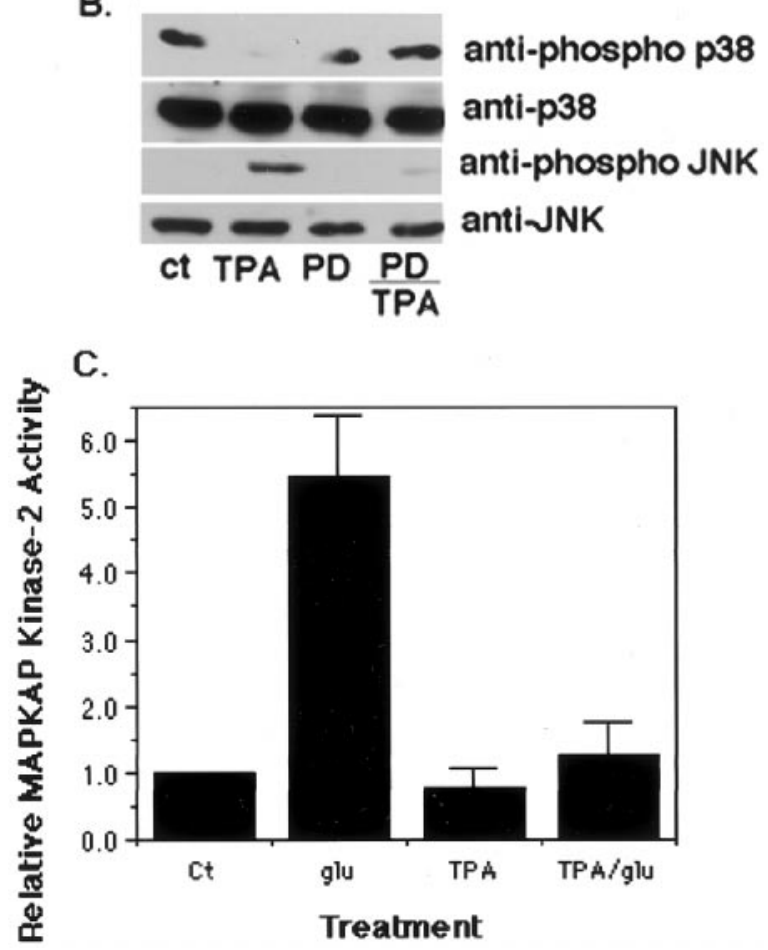

Figure 3. Effects of glutamate and TPA on p38 MAPK and JNK activities. $A$, HT22 cells were untreated $(c t)$ or treated with $100 \mathrm{ng} / \mathrm{ml}$ TPA (TPA), $5 \mathrm{~mm}$ glutamate $(g l u)$, or glutamate plus TPA (TPA/glu) for $8 \mathrm{hr}$. The cells were scraped into sample buffer and analyzed by SDS-PAGE and immunoblotting with an antibody specific for phosphorylated p38 MAPK (anti-phospho p38) and an antibody that detects phosphorylated and unphosphorylated p38 MAPK (anti-p38) or an antibody specific for phosphorylated JNK (anti-phospho JNK) and an antibody that detects phosphorylated and unphosphorylated JNK (anti-JNK). Similar results were obtained in five independent experiments. $B$, HT22 cells were untreated $(c t)$ or treated with $100 \mathrm{ng} / \mathrm{ml}$ TPA $(T P A), 50 \mu \mathrm{M}$ PD98059 $(P D)$, or PD98059 and TPA $(P D / T P A)$ for $1 \mathrm{hr}$. Cells were pretreated with PD98059 for $1 \mathrm{hr}$ before the addition of TPA. The cells were scraped into sample buffer and analyzed by SDS-PAGE and immunoblotting with antibodies specific for the activated forms of p38 MAP kinase (antiphospho p38) and JNK (anti-phospho JNK), as well as with antibodies that recognize both active and inactive forms of these proteins (anti-p38, anti-JNK). Similar results were obtained in three independent experiments. $C$, The effect of TPA and glutamate on MAPKAP kinase-2 activity. HT22 cells were untreated $(C t)$ or treated with $5 \mathrm{~mm}$ glutamate ( $g l u), 100 \mathrm{ng} / \mathrm{ml}$ TPA (TPA), or TPA plus glutamate $(T P A / g l u)$ for $8 \mathrm{hr}$. The cells were then solubilized in Triton X-100 buffer, MAPKAP kinase-2 was immunoprecipitated from the extracts, and the kinase activity was assayed using a peptide substrate and liquid scintillation counting. The results represent the average of four independent experiments.

consistent with an inhibition of phosphatase activity by sodium orthovanadate, suggesting that the downregulation of p38 MAPK activity is attributable to the ERK-dependent activation of one or more MKPs. Interestingly, sodium orthovanadate stimulated the activation of JNK isoforms distinct from those activated by TPA 
A.
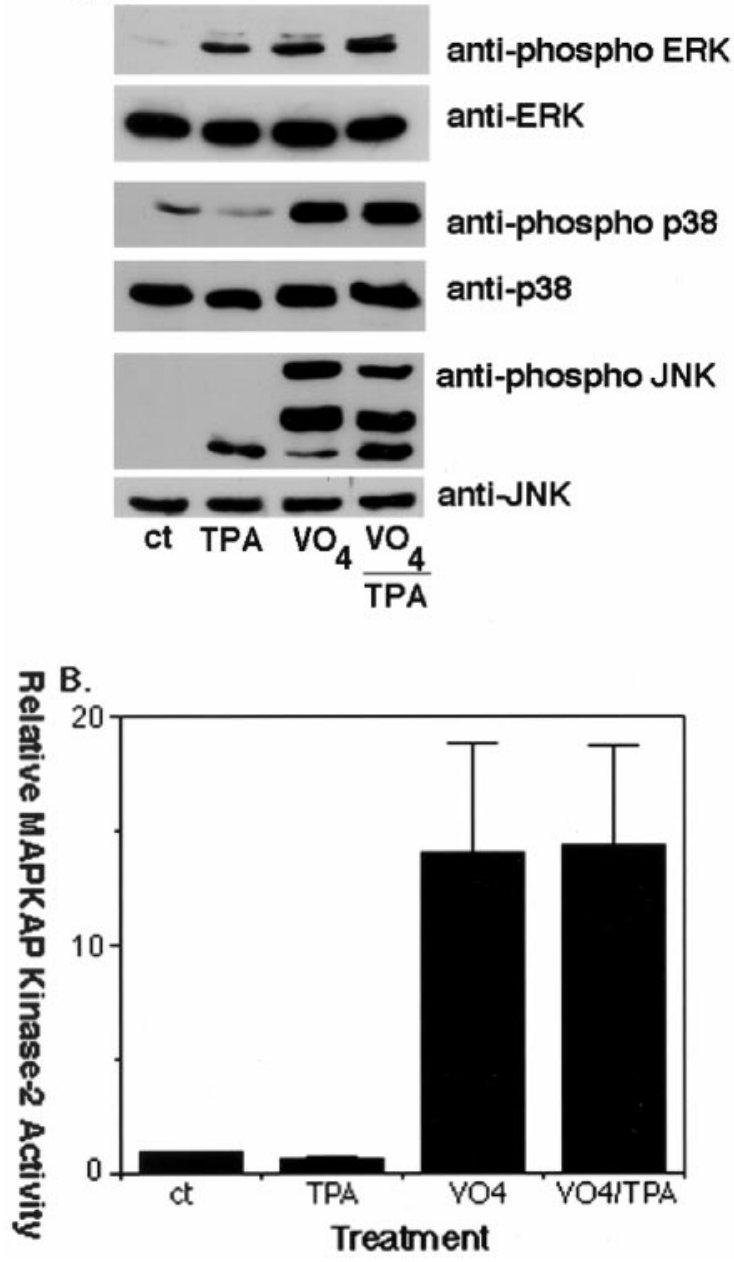

Figure 4. A, TPA-dependent activation of p38 MAPK is inhibited by sodium orthovanadate. HT22 cells were untreated $(c t)$ or treated with 100 $\mathrm{ng} / \mathrm{ml}$ TPA $(T P A), 1 \mathrm{~mm}$ sodium orthovanadate $\left(V O_{4}\right)$, or TPA plus sodium orthovanadate $\left(V O_{4} / T P A\right)$ for $1 \mathrm{hr}$. Cells were pretreated with sodium orthovanadate for $1 \mathrm{hr}$ before the addition of TPA. The cells were scraped into sample buffer and analyzed by SDS-PAGE and immunoblotting with antibodies specific for the activated forms of ERK (anti-phospho ERK), p38 MAP kinase (anti-phospho p38), and JNK (anti-phospho $J N K$ ), as well as with antibodies that recognize both active and inactive forms of these proteins (anti-ERK, anti-p38, anti-JNK). Similar results were obtained in three independent experiments. $B$, The effect of sodium orthovanadate on MAPKAP kinase-2 activity. HT22 cells were untreated $(c t)$ or treated with $100 \mathrm{ng} / \mathrm{ml}$ TPA $(T P A), 1 \mathrm{~mm}$ sodium orthovanadate $\left(\mathrm{VO}_{4}\right)$, or TPA plus sodium orthovanadate $\left(\mathrm{VO}_{4} / \mathrm{TP} A\right)$ for $1 \mathrm{hr}$. Cells were pretreated with sodium orthovanadate for $1 \mathrm{hr}$ before the addition of TPA. The cells were then solubilized in Triton X-100 buffer, MAPKAP kinase-2 was immunoprecipitated from the extracts, and kinase activity was assayed using a peptide substrate and liquid scintillation counting. The results represent the average of four independent experiments.

(Fig. 4A). These data further indicate that the activities of JNK and p38 MAPK are regulated independently by ERKs and suggest that the phosphatase activity induced by TPA activation of ERKs is specific to p38 MAPK.

To determine whether p38 MAPK activation plays a role in oxidative glutamate toxicity, I used two specific inhibitors of p38 MAPK activity, SB202190 and SB203580 (Cohen, 1998), and tested their ability to block cell death. Both of these compounds effectively inhibited cell death induced by several different forms of oxidative stress, including glutamate treatment (Fig. $5 A$ ), con-

\section{A. HT22 Cells}
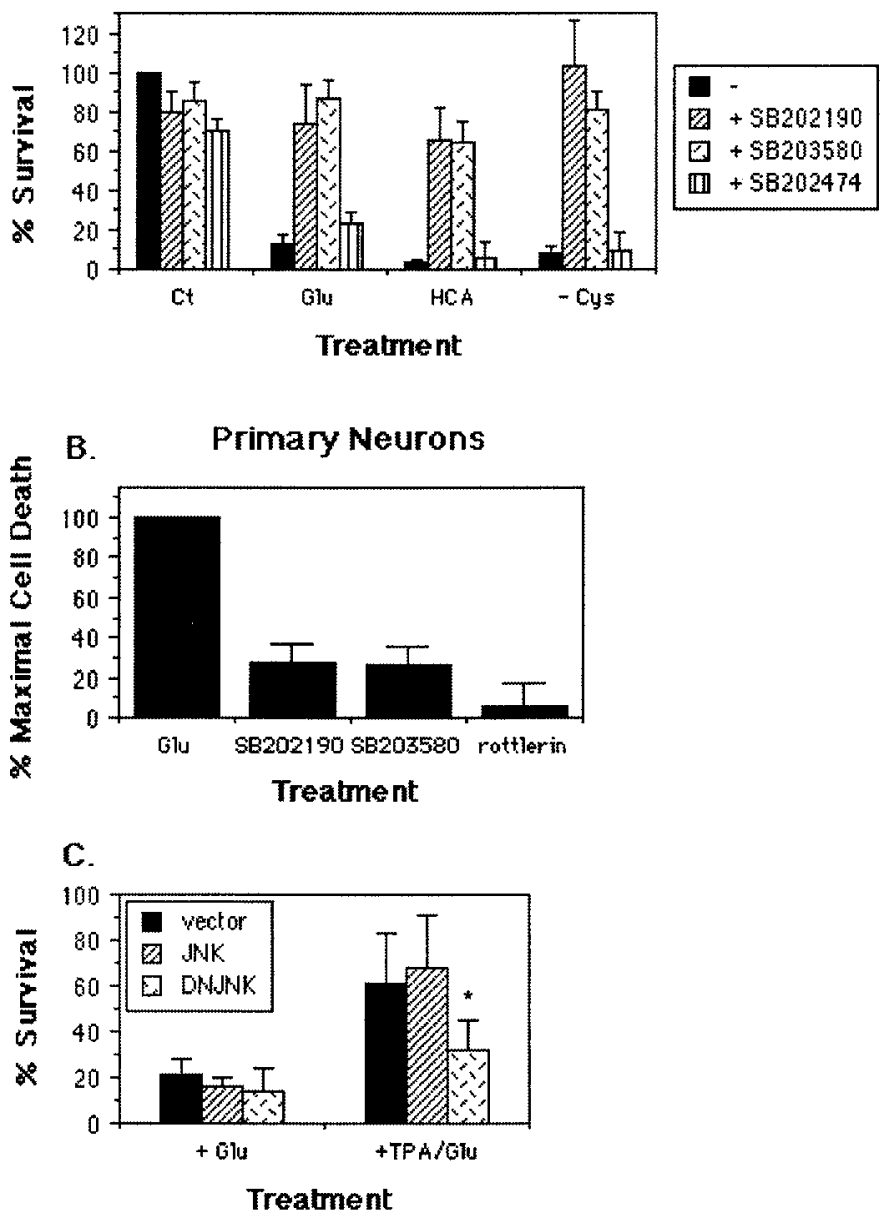

Figure 5. JNK activation and p38 MAPK inactivation play roles in TPA-mediated protection from oxidative glutamate toxicity. A, HT22 cells were treated with $5 \mathrm{~mm}$ glutamate $(G l u), 2.5 \mathrm{~mm} \mathrm{HCA}(H C A)$, or cysteine-free medium $(-C y s)$ in the absence or presence of $10 \mu \mathrm{M}$ SB202190, SB203580, or SB202474. Percent survival was measured after $24 \mathrm{hr}$ by the MTT method. The data represent the mean $\pm \mathrm{SD}$ of three independent experiments, with each point done in quadruplicate. $B$, Primary cortical neurons were treated with $5 \mathrm{~mm}$ glutamate $(\mathrm{Glu})$ in the absence or presence of $10 \mu \mathrm{M} \mathrm{SB} 202190$ or SB203580 or $0.5 \mu \mathrm{M}$ rottlerin. Cell survival was measured after $24 \mathrm{hr}$ by the MTT method, and the results are presented as the percentage of the cell death seen in the presence of glutamate $(30-40 \%)$, which is arbitrarily set at $100 \%$. The data represent the mean $\pm \mathrm{SD}$ of a single experiment, with each point done in quadruplicate. Similar results were obtained in two independent experiments. $C$, HT22 cells were transfected with DN-JNK or empty vector along with pcDNA/lac Z. Twenty-four hours later, the cells were treated with $5 \mathrm{~mm}$ glutamate in the absence or presence of $100 \mathrm{ng} / \mathrm{ml}$ TPA. After $24 \mathrm{hr}$, the cells were fixed and stained with X-gal, and the number of blue cells in five independent fields was counted. The data represent the mean \pm SD of five independent experiments. * indicates significantly different from vector with TPA plus glutamate and JNK with TPA plus glutamate ( $p=0.02$; ANOVA).

firming a critical role for p38 MAPK activity in promoting cell death. Neither compound had any effect on either the decrease in glutathione levels or the increase in ROS production brought about by treatment with glutamate (data not shown), further indicating that the pathways regulated by TPA do not directly affect ROS production. In contrast, an inactive analog of these compounds, SB202474, was not effective at inhibiting oxidative stress-induced cell death (Fig. $5 A$ ). Similar results were obtained with primary cortical neurons (Fig. $5 B$ ). 
To assess the role of JNK activation in TPA-mediated protection from oxidative glutamate toxicity, I used DN-JNK, which blocks JNK activation in several different cell types (Sanna et al., 1998). Cells were cotransfected with plasmids containing DNJNK and $l a c Z$ to mark the transfected cells and then treated with TPA and/or glutamate. As shown in Figure 5C, expression of DN-JNK reduced the protective effect afforded by TPA treatment by $\sim 50 \%$, whereas wild-type JNK had no effect on cell survival under any of the conditions tested. Together, these experiments indicate that both the activation of JNK and the inactivation of $\mathrm{p} 38 \mathrm{MAPK}$ are required for the protective actions of TPA treatment.

To understand further how PKC activation mediates protection from oxidative stress-induced cell death, the possible PKC isozymes involved in this protection must be identified. The PKC family at present contains 10 different members, which can be divided into three groups on the basis of structure and cofactor requirements (for review, see Hug and Sarre, 1993; Nishizuka, 1995; Jaken, 1996; Mochly-Rosen and Kauvar, 1998). Conventional PKCs $(\alpha, \beta 1, \beta 2$, and $\gamma)$ require negatively charged phospholipids, calcium, and diacylglycerol (DAG) for optimal activity, whereas novel PKCs $(\delta, \epsilon, \eta / \Delta$, and $\theta)$ require only phospholipids and DAG. Members of both of these groups are also activated by phorbol esters, such as TPA, which interact with the same site as DAG and eliminate the need for other cofactors. Atypical PKCs ( $\zeta$ and $\lambda / \iota$ ) do not require either calcium or DAG for maximal activity and are not activated by phorbol esters. Similar to many other types of cells, the HT22 cells express multiple PKC isozymes, including the $\mathrm{cPKC}, \mathrm{PKC} \alpha$, the $\mathrm{nPKCs}, \mathrm{PKC} \delta$ and PKC $\epsilon$, and the aPKCs, PKC $\zeta$, and PKC $\lambda$ (Fig. 6A). The HT22 cells do not express PKC $\beta 1, \operatorname{PKC} \beta 2, \operatorname{PKC} \gamma$, or PKC $\theta$ (data not shown). To begin to determine which PKC isozymes are involved in the protection from cell death, I took advantage of the observation that treatment of cells with a high dose of TPA for $24 \mathrm{hr}$ both downregulates conventional and novel PKC isozymes (Szallasi et al., 1994) and blocks the protective effect of TPA on the HT22 cells (Davis and Maher, 1994). When the levels of the different PKC isozymes after a $24 \mathrm{hr}$ treatment with $1 \mu \mathrm{g} / \mathrm{ml}$ TPA were examined, the levels of $\mathrm{PKC} \alpha, \mathrm{PKC} \delta$, and $\mathrm{PKC} \epsilon$ were all reduced significantly (Fig. 6A). As expected, the levels of the aPKCs, PKC $\zeta$, and PKC $\lambda$ were unchanged. These data confirm that TPA-mediated protection from cell death is dependent on conventional and/or novel PKC isozymes.

To determine whether the $\mathrm{nPKC}, \mathrm{PKC} \delta$, was involved in the protective response elicited by TPA treatment, I used the relatively specific PKC $\delta$ inhibitor rottlerin (Hofmann, 1997; Corbit et al., 1999). Rottlerin had no effect on the activation of ERK and JNK and the inactivation of p38 MAPK by TPA (Fig. 6B). Furthermore, rottlerin did not block the protective effect of TPA but instead inhibited oxidative glutamate toxicity (Fig. 6C), suggesting that $\mathrm{PKC} \delta$ plays a positive role in promoting cell death. Rottlerin also blocked glutamate-induced cell death in primary cortical neurons (Fig. 5B).

Along with rottlerin, I tested several other, more general PKC inhibitors for their effects on both the activities of the different MAPK family members and the TPA-mediated protection from cell death. $\mathrm{G}_{\mathrm{o}} 6983$, which inhibits the activity of all PKC isozymes except PKC $\mu$ (Zeidman et al., 1999), blocked ERK activation, JNK activation, and p38 MAPK inactivation (Fig. 6B), as well as the inhibition of glutamate-induced cell death mediated by TPA (Fig. 6C). $\mathrm{R}_{\mathrm{o}}$ 318220, which at the concentration used inhibits both cPKCs and nPKCs (Wilkinson et al., 1993), reduced ERK and

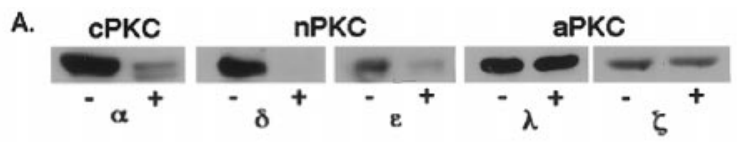

B.
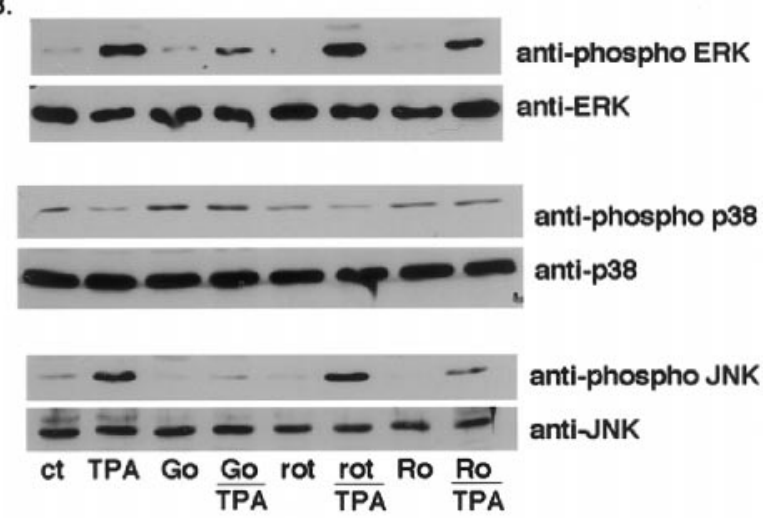

C.

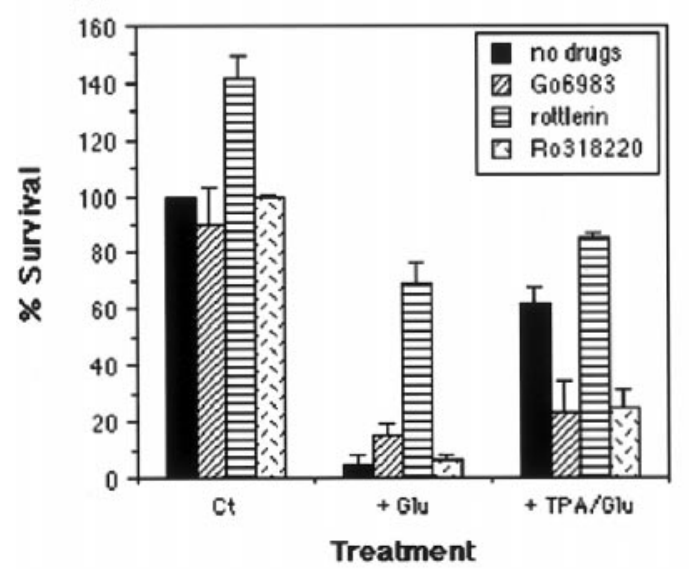

Figure 6. Analysis of PKC isozymes involved in TPA-mediated protection from oxidative glutamate toxicity. A, HT22 cells were untreated (-) or treated $(+)$ for $24 \mathrm{hr}$ with $1 \mu \mathrm{g} / \mathrm{ml} \mathrm{TPA}$. The cells were scraped into sample buffer, and equal amounts of protein were analyzed by SDSPAGE and immunoblotting with antibodies specific for each of the indicated PKC isozymes. Similar results were obtained in two independent experiments. $B$, HT22 cells were untreated $(c t)$ or pretreated for $1 \mathrm{hr}$ with $1 \mu \mathrm{M} \mathrm{G}_{\mathrm{o}} 6983$ (Go), $5 \mu \mathrm{M}$ rottlerin (rot), or $1 \mu \mathrm{M} \mathrm{R} 318220$ (Ro) before the addition of $100 \mathrm{ng} / \mathrm{ml}$ TPA (TPA, rott/TPA, Go/TPA, Ro/TPA) for $1 \mathrm{hr}$. The cells were scraped into sample buffer and analyzed by SDS-PAGE and immunoblotting with antibodies specific for the activated forms of ERK (anti-phospho ERK), p38 MAP kinase (anti-phospho p38), and JNK (anti-phospho JNK), as well as with antibodies that recognize both active and inactive forms of these proteins (anti-ERK, anti-p38, anti-JNK). Similar results were obtained in three independent experiments. $C$, HT22 cells were untreated $(C t)$ or treated with $5 \mathrm{~mm}$ glutamate $(G l u)$ in the absence or presence of TPA and/or $5 \mu \mathrm{M}$ rottlerin (rott), $1 \mu \mathrm{M} \mathrm{G} \mathrm{G}_{\mathrm{o}} 6983$ (Go), or $1 \mu \mathrm{M} \mathrm{R} 318220(R o)$. Percent survival was measured after $24 \mathrm{hr}$ by the MTT method. The data represent the mean \pm SD of six independent experiments, with each point done in quadruplicate.

JNK activation and inhibited p38 MAPK inactivation (Fig. 6B) and also reduced the TPA-mediated protection from cell death (Fig. 6C). These data lend support to the studies with the more isozyme-specific PKC inhibitor rottlerin and also show that the effects of TPA on cell survival are mediated through its activation of PKC.

The ability of rottlerin to protect the HT22 cells from oxidative glutamate toxicity suggested an apparent contradiction in my 
A.

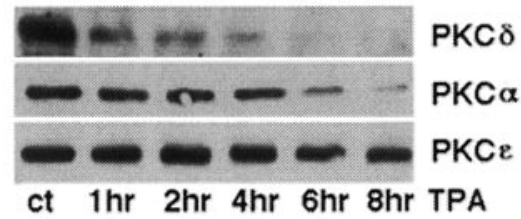

B.

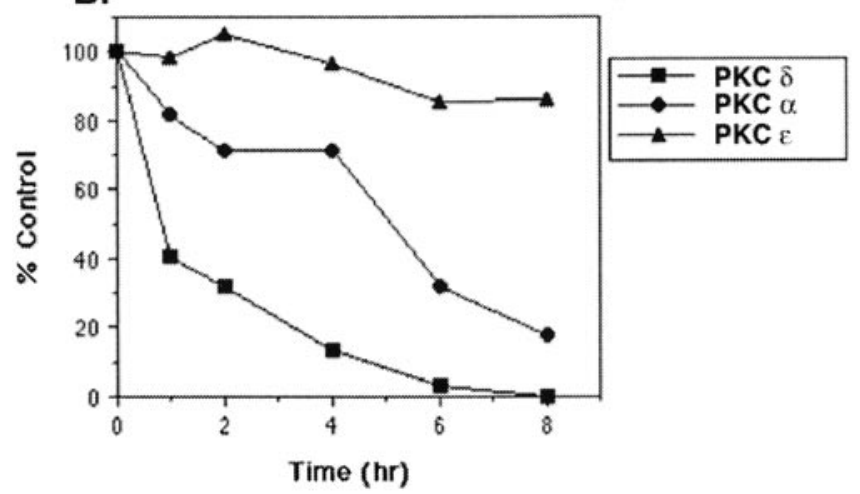

Figure 7. TPA treatment causes the rapid downregulation of PKC $\delta . A$, Immunoblot. Cells were untreated $(c t)$ or treated with $100 \mathrm{ng} / \mathrm{ml}$ TPA for 1-8 hr, cell extracts were prepared, and equal amounts of protein were analyzed by SDS-PAGE and immunoblotting with antibodies specific for each of the indicated PKC isozymes. Similar results were obtained in three independent experiments. $B$, The data shown in $A$ are presented graphically.

results because TPA should activate PKC $\delta$ along with the other cPKCs and nPKCs present in the HT22 cells. To resolve this contradiction, the effects of TPA on the levels of the different PKC isozymes were examined at different times after TPA addition (Fig. 7A). TPA induces the rapid and complete loss of $\mathrm{PKC} \delta$ (Fig. 7B). In contrast, the levels of PKC $\alpha$ decrease much more slowly, and PKC $\epsilon$ is present at a constant level for up to $8 \mathrm{hr}$ after TPA addition (Fig. 7B). The TPA-mediated downregulation of PKC $\delta$ is not inhibited by PD98059 (data not shown), indicating that it occurs independently of the effect of TPA on ERK activity. Thus, in addition to activating ERKs, TPA treatment also leads to the downregulation of PKC $\delta$ whose activity, based on the data with rottlerin, appears to contribute to oxidative stress-induced cell death. Furthermore, the observation that the PKC inhibitor $\mathrm{G}_{\mathrm{o}} 6983$, which inhibits $\mathrm{PKC} \delta$ along with all the other PKC isozymes expressed in the HT22 cells, does not protect the cells from oxidative stress-induced cell death and blocks TPAmediated protection (Fig. $6 \mathrm{C}$ ) suggests that the activities of multiple PKC isozymes are required for cell survival.

\section{DISCUSSION}

The above results demonstrate that the TPA-mediated protection of neuronal cells from oxidative stress-induced cell death involves the regulation of multiple kinases, including several different members of the MAPK family (Fig. 8). Although MAPKs have been implicated in cell death in a variety of studies, the work presented here shows for the first time that the control of these activities is interrelated. This, therefore, may be why in studies using dominant-negative mutants, the dynamic balance between ERK activity on the one hand and JNK and p38 MAPK activities on the other hand, appears to be a critical factor in determining whether nerve cells live or die (Xia et al., 1995). My work also
TPA-Mediated Pathways to Neuroprotection

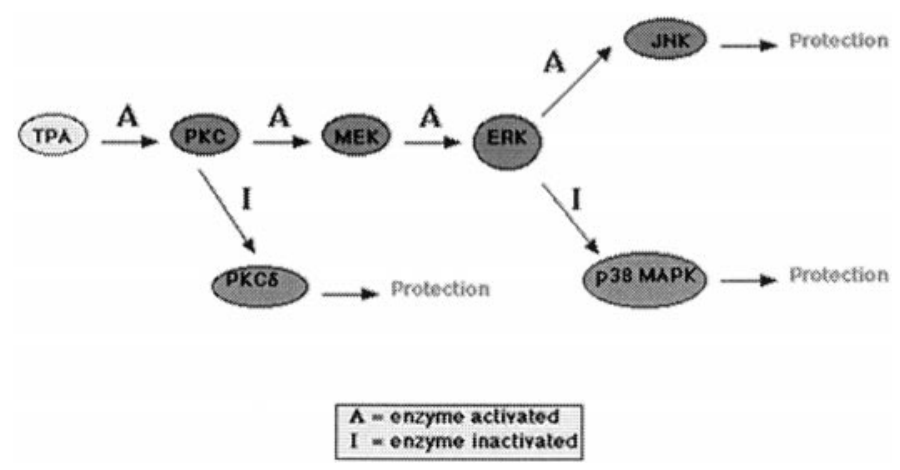

Figure 8. A model diagramming the multiple actions of TPA on intracellular kinases that lead to protection from oxidative stress-induced cell death. TPA treatment results in the activation of multiple PKC isozymes. PKC activation, in turn, leads to the activation of ERKs, which induce the activation of JNK and the inactivation of p38 MAPK. Both the activation of JNK and the inactivation of p38 MAPK are required for protection from oxidative stress-induced cell death. TPA treatment also leads to the rapid inactivation of $\mathrm{PKC} \delta$, which is independent of the effect on ERK activity and also plays a role in the protection from cell death.

provides insight into why studies with different PKC inhibitors in models of ischemia and other forms of neuronal cell death have not produced consistent results since different PKC isozymes play opposing roles in modulating oxidative stress-induced cell death.

Since the discovery that PKCs serve as the major intracellular receptors for tumor-promoting phorbol esters, they have been implicated in the regulation of cell proliferation. More recently, the role of PKCs in regulating PCD has been investigated (for review, see Lavin et al., 1996; Deacon et al., 1997; Mochly-Rosen and Kauvar, 1998). Several studies have suggested roles for $\mathrm{PKC} \alpha, \mathrm{PKC} \epsilon, \mathrm{PKC} \zeta$, and $\mathrm{PKC} \lambda / \iota$ in the suppression of $\mathrm{PCD}$ (Murray and Fields, 1997; Gubina et al., 1998; Whelan and Parker, 1998). The results presented here indicate that both $\mathrm{PKC} \alpha$ and PKC $\epsilon$ play a role in the TPA-mediated protection of neuronal cells from oxidative stress-induced cell death and that they do so, at least in part, by activating ERKs and JNK and inhibiting p38 MAPK activation.

In contrast, both $\mathrm{PKC} \beta \mathrm{I}$ and $\mathrm{PKC} \delta$ have been associated with the promotion of PCD (Deacon et al., 1997; Konishi et al., 1999). PKC $\delta$ is activated during PCD via either cleavage by caspase 3 (Gschwendt, 1999) or an allosteric mechanism (Fujii et al., 2000). Furthermore, overexpression of PKC $\delta$ can induce (Ghayur et al., 1996; Li et al., 1999) or potentiate (Konishi et al., 1999) PCD. My results are consistent with a role for $\mathrm{PKC} \delta$ in promoting oxidative stress-induced cell death in neuronal cells. However, because caspase 3 inhibitors do not protect the HT22 cells from oxidative glutamate toxicity (Tan et al., 1998b) and no cleavage of PKC $\delta$ is observed after glutamate treatment (data not shown), it is likely that the activation of PKC $\delta$ by glutamate treatment is through an undefined allosteric mechanism (Fujii et al., 2000).

The role of ERKs in PCD is controversial. ERK activation blocks PCD induced by a variety of stimuli (Xia et al., 1995; Guvillier et al., 1996; Guyton et al., 1996; Stadheim and Kucera, 1998; Wang et al., 1998; Singer et al., 1999). However, others found that ERK activation either plays no role in PCD (Creedon et al., 1996) or actually promotes PCD (Murray et al., 1998; Alessandrini et al., 1999; Stanciu et al., 2000). Two of the latter 
studies (Satoh et al., 2000; Stanciu et al., 2000) also used the HT22 cells and, in contrast to the results presented here, found that a different MEK inhibitor, U0126, protected the cells from oxidative glutamate toxicity. However, unlike PD98059, U0126 also inhibits p70 ${ }^{\mathrm{S} 6 \mathrm{~K}}$ (Fukazawa and Uehara, 2000). p70 ${ }^{\mathrm{S} 6 \mathrm{~K}}$ controls the translation of specific mRNAs (for review, see Dufner and Thomas, 1999), and the partial inhibition of protein synthesis protects the HT22 cells from oxidative glutamate toxicity (Tan et al., 1998b). Therefore, the protective effect of U0126 may not involve its action on MEK.

As with ERKs, the role of JNK in PCD is controversial. Initial evidence suggested that high levels of JNK activity contributed to cell death, whereas inhibition of JNK activation was protective (Xia et al., 1995). However, later studies demonstrated a protective role for JNK activation in several different cell death paradigms (Roulston et al., 1998; Sanna et al., 1998). One complicating factor is that the JNK family is encoded by three different genes with alternative splicing giving rise to 10 different isoforms (Kyriakis and Avruch, 1996; Cohen, 1998; Leppa and Bohmann, 1999), and different JNK isoforms are not functionally redundant. For example, although JNK3 knock-out mice show an increased resistance to kainic acid-induced seizures and subsequent PCD of hippocampal neurons, mice deficient in both JNK1 and JNK2 have a severe dysregulation of neuronal PCD during development (Kuan et al., 1999). The data presented here indicate that JNK is activated by TPA treatment of nerve cells and that this activation contributes to the protective effects of TPA. PKC activates JNK occurs in several cell types (Kawakami et al., 1998; Hara et al., 1999; McClellan et al., 1999; Okumura et al., 1999) in response to a variety of stimuli. Although the mechanism underlying this activation is unclear, in my study, JNK activation appears to be mediated by ERKs because it is blocked by the MEK inhibitor PD98059.

The role of p38 MAPK in PCD is less controversial. Using specific p38 MAPK inhibitors, a number of studies demonstrated that inhibition of p38 MAPK activity promotes cell survival in both neuronal (Kawsaski et al., 1997; Kummer et al., 1997; Horstmann et al., 1998; Behrens et al., 1999) and non-neuronal (Mackay and Mochly-Rosen, 1998; Ma et al., 1999) cells. However, the role of p38 MAPK may be cell type- and/or stressspecific because a few other studies have not demonstrated a role for this kinase in PCD (Gunn-Moore and Tavare, 1998; Zhang et al., 1999). In the HT22 cells, the role of p38 MAPK in oxidative stress-induced cell death appears to be a negative one because glutamate treatment leads to p38 MAPK activation, and specific inhibitors of this kinase block cell death. Furthermore, TPA treatment leads to the rapid inactivation of p38 MAPK via a pathway requiring ERK activity.

One strong possibility for the inactivation of p38 MAPK by TPA is that it is through one of the members of the MKP family of dual-specificity phosphatases. This possibility is supported by the data with the tyrosine phosphatase inhibitor sodium orthovanadate (Fig. 4). The eight members of the MKP family exhibit distinct cellular localizations and substrate specificity. In the CNS, MKP-1 expression is upregulated after kainate treatment (Boscher et al., 1998) and ischemia and axotomy (Winter et al., 1998), and, in the latter two cases, its upregulation was restricted to those populations of cells that survive the injury. Furthermore, TPA treatment of cells can induce the synthesis of MKP-1 (Kwak et al., 1994) by a pathway that requires ERK activity (Franklin and Kraft, 1997). However, it is unlikely that TPA treatment of the HT22 cells is inducing synthesis of MKP-1 because the downregulation of p38 MAPK phosphorylation is apparent within 5 min after addition of TPA to cells (data not shown). Alternatively, the TPA-dependent inactivation of p38 MAPK may be mediated by a protein tyrosine phosphatase that specifically acts on p38 MAPK. Recently, a role for protein tyrosine phosphatases in the actions of PKC in $\mathrm{T}$ cells was demonstrated (Tsuchida et al., 2000).

Glutamate directly affects the activities of p38 MAPK and ERK but alone does not appear to alter JNK activity. Because in TPA-treated cells the decrease in p38 MAPK activity is directly dependent on ERK activity, it is likely that the increase in p38 MAPK activity induced by glutamate treatment is a consequence of the inactivation of ERK activity. Thus, the actions of TPA appear to be severalfold (Fig. 8): first, to counteract the effects of glutamate on two MAPK family members; second, to activate an additional family member whose activity promotes cell survival; and third, to inactivate a specific PKC isozyme, PKC $\delta$. Although agents that induce oxidative stress do not always inactivate ERKs (Guyton et al., 1996; Wang et al., 1998), this may be more a reflection of the heterogeneous response of a population of cells rather than a cell type-specific effect of these agents on ERK activity. Thus, the cells within a population in which ERKs are activated live, whereas those in which it is inhibited die. In contrast, because glutamate kills $90-95 \%$ of the cells, we can focus specifically on pathways leading to cell death.

In summary, a critical part of the protection from oxidative stress-induced cell death mediated by protein kinase $\mathrm{C}$ activation is attributable to the modulation of the activities of multiple members of the MAPK kinase family. However, these activities do not appear to be regulated independently by $\mathrm{PKC}$, but rather their activities appear to be interconnected. Thus, activation of ERKs by TPA leads to the downregulation of p38 MAPK activity and the upregulation of JNK activity. An additional effect of TPA treatment is to differentially modulate the levels of different members of the PKC family such that a specific isozyme that appears to promote cell death is lost, whereas other isozymes are maintained and may contribute to the extended activation of ERKs. These other isozymes may also have additional survivalpromoting effects that remain to be determined.

\section{REFERENCES}

Alessandrini A, Namura S, Moskowitz MA, Bonventre JV (1999) MEK1 protein kinase inhibition protects against damage resulting from focal cerebral ischemia. Proc Natl Acad Sci USA 96:12866-12869.

Ames BN, Shigenaga MK, Hagen TM (1993) Oxidants, antioxidants, and the degenerative diseases of aging. Proc Natl Acad Sci USA 90:7915-7922.

Ausubel FM, Brent R, Kingston RE, Moore DD, Seidman JG, Smith JA, Struhl K (1999) Current protocols in molecular biology, pp 9.10.99.10.10. New York: Wiley.

Beal MF (1995) Aging, energy, and oxidative stress in neurodegenerative diseases. Ann Neurol 38:357-366.

Behrens MM, Strasser U, Koh JY, Gwag BJ, Choi DW (1999) Prevention of neuronal apoptosis by phorbol ester-induced activation of protein kinase C: blockade of p38 mitogen-activated protein kinase. Neuroscience 94:917-927.

Boscher U, Dickinson R, Muda M, Camps M, Arkinstall S (1998) Regulated expression of dual specificity protein phosphatases in rat brain. NeuroReport 9:4081-4086.

Cohen P (1998) The search for physiological substrates of MAO and SAP kinases in mammalian cells. Trends Cell Biol 7:353-361.

Cook JA, Mitchell JB (1989) Viability measurements in mammalian cell systems. Anal Biochem 179:1-7.

Corbit KC, Foster DA, Rosner MR (1999) Protein kinase C $\delta$ mediates neurogenic but not mitogenic activation of mitogen-activated protein kinase in neuronal cells. Mol Cell Biol 19:4209-4218.

Coyle JT, Puttfarcken P (1993) Oxidative stress, glutamate, and neurodegenerative disorders. Science 262:689-695.

Creedon DJ, Johnson EM, Lawrence JC (1996) Mitogen-activated protein kinase-independent pathways mediate the effects of nerve growth factor and cAMP on neuronal survival. J Biol Chem 271:20713-20718. 
Davis JB, Maher P (1994) Protein kinase C activation inhibits glutamate-induced cytotoxicity in a neuronal cell lines. Brain Res 652:169-173.

Deacon EM, Pongracz J, Griffiths G, Lord JM (1997) Isoenzymes of protein kinase $\mathrm{C}$ : differential involvement in apoptosis and pathogenesis. J Clin Pathol 50:124-131.

Dufner A, Thomas G (1999) Ribosomal S6 kinase signaling and the control of translation. Exp Cell Res 253:100-109.

Durkin JP, Tremblay R, Chakravarthy B, Mealing G, Morley P, Small D, Song D (1997) Evidence that the early loss of membrane protein kinase $\mathrm{C}$ is a necessary step in the excitatory amino acid-induced death of primary cortical neurons. J Neurochem 68:1400-1412.

Franklin C, Kraft AS (1997) Conditional expression of the mitogenactivated protein kinase (MAPK) phosphatase MKP-1 preferentially inhibits p38 MAPK and stress-activated protein kinase in U937 cells. J Biol Chem 272:16917-16923.

Fujii T, Garcia-Bermejo ML, Bernabo JL, Caamano J, Ohba M, Kuroki T, Li L, Yuspa SH, Kazanietz MG (2000) Involvement of protein kinase $\mathrm{C} \delta$ in phorbol ester-induced apoptosis in LNCaP prostate cancer cells. J Biol Chem 275:7574-7582.

Fukazawa H, Uehara Y (2000) U0126 reverses Ki-ras-mediated transformation by blocking both mitogen-activated protein kinase and p70 S6 kinase pathways. Cancer Res 60:2104-2107.

Ghayur T, Hugunin M, Talanian RV, Ratnofsky W, Quinlan C, Emoto Y, Pandey P, Datta R, Huang Y, Kharbanda S, Allen H, Kamen R, Wong W, Kufe D (1996) Proteolytic activation of protein kinase C delta by an ICE/CED 3-like protease induces characteristics of apoptosis. J Exp Med 184:2399-2404.

Gschwendt M (1999) Protein kinase C $\delta$. Eur J Biochem 259:555-564.

Gubina E, Rinaudo MS, Szallasi Z, Blumberg PM, Mufson RA (1998) Overexpression of protein kinase $\mathrm{C}$ isoform $\epsilon$ but not $\delta$ in human interleukin-3-dependent cells suppresses apoptosis and induces Bcl-2 expression. Blood 91:823-829.

Gunn-Moore FJ, Tavare JM (1998) Apoptosis of cerebellar granule cells induced by serum withdrawal, glutamate or $\beta$-amyloid, is independent of jun kinase or p38 mitogen activated protein kinase activation. Neurosci Lett 250:53-56.

Guvillier O, Pirianov G, Kleuser B, Vanek PG, Coso OA, Gutkind JS, Spiegel S (1996) Suppression of ceramide-mediated programmed cell death by sphingosine-a-phosphate. Nature 381:800-803.

Guyton KZ, Liu Y, Gorospe M, Xy Q, Holbrook NJ (1996) Activation of mitogen-activated protein kinase by $\mathrm{H}_{2} \mathrm{O}_{2}$. J Biol Chem 271:4138-4142.

Haneda M, Sugimoto T, Kikkawa R (1998) Mitogen-activated protein kinase phosphatase: a negative regulator of the mitogen-activated protein kinase cascade. Eur J Pharmacol 365:1-7.

Hansen MB, Nielsen SE, Berg K (1989) Re-examination and further development of a precise and rapid dye method for measuring cell growth/cell kill. J Immunol Methods 119:203-210.

Hara T, Namba H, Takamura N, Yang TT, Nagayama Y, Fukata S, Kuma K, Ishikawa N, Ita K, Yamashita S (1999) Thyrotropin regulates c-Jun N-terminal kinase (JNK) activity through two distinct signal pathways in human thyroid cells. Endocrinology 140:1724-1730.

Hofmann J (1997) The potential for isoenzyme-selective modulation of protein kinase C. FASEB J 11:649-669.

Horstmann S, Kahle PJ, Borasio GD (1998) Inhibitors of p38 mitogenactivated protein kinase promote neuronal survival in vitro. J Neurosci Res 52:483-490.

Hug H, Sarre TF (1993) Protein kinase C isoenzymes: divergence in signal transduction? Biochem J 291:329-343.

Jaken S (1996) Protein kinase C isozymes and substrates. Curr Opin Cell Biol 8:168-178.

Kawakami Y, Hartman SE, Holland PM, Cooper JA, Kawakami T (1998) Multiple signaling pathways for the activation of JNK in mast cells: involvement of Bruton's tyrosine kinase, protein kinase $\mathrm{C}$, and JNK kinases, SEK1 and MKK7. J Immunol 161:1795-1802.

Kawsaski H, Morooka T, Shimohama S, Kimura J, Hirano T, Gotoh Y, Nishida E (1997) Activation and involvement of p38 mitogenactivated protein kinase in glutamate-induced apoptosis in rat cerebellar granule cells. J Biol Chem 272:18518-18521.

Keyse SM (1999) The role of protein phosphatases in the regulation of mitogen and stress-activated protein kinases. Free Radic Res 31:341-349.

Konishi H, Matsuzaki H, Takaishi H, Yamamoto T, Fukunaga M, Ono Y, Kikkawa U (1999) Opposing effects of protein kinase $\mathrm{C} \delta$ and protein kinase $\mathrm{B} \alpha$ on $\mathrm{H}_{2} \mathrm{O}_{2}$-induced apoptosis in $\mathrm{CHO}$ cells. Biochem Biophys Res Commun 264:840-846.

Koroshetz WJ, Moskowitz MA (1996) Emerging treatments for stroke in humans. Trends Physiol Sci 17:227-233.

Kuan CY, Yang DD, Roy DRS, Davis RJ, Pakic P, Flavell RA (1999) The Jnk1 and Jnk2 protein kinases are required for regional specific apoptosis during early brain development. Neuron 22:667-676.

Kummer JL, Rao PK, Heidenreich KA (1997) Apoptosis induced by withdrawal of trophic factors in mediated by p38 mitogen-activated protein kinase. J Biol Chem 272:20490-20494.

Kwak SP, Hakes DJ, Martell KJ, Dixon JE (1994) Isolation and charac- terization of a human dual specificity protein-tyrosine phosphatase gene. J Biol Chem 269:3596-3604.

Kyriakis JM, Avruch J (1996) Protein kinase cascades activated by stress and inflammatory cytokines. BioEssays 18:567-577.

Lavin MF, Latters D, Song Q (1996) Role of protein kinase activity in apoptosis. Experentia 52:979-994.

Leppa S, Bohmann D (1999) Diverse functions of JNK signaling and c-Jun in stress response and apoptosis. Oncogene 18:6158-6162.

Li L, Lorenzo PS, Bogi K, Blumberg PM, Yuspa SH (1999) Protein kinase $\mathrm{C} \delta$ targets mitochondria, alters mitochondrial membrane potential, and induces apoptosis in normal and neoplastic keratinocytes when overexpressed by an adenoviral vector. Mol Cell Biol 19:8547-8558.

Li Y, Maher P, Schubert D (1997a) Requirement for cGMP in nerve cell death caused by glutathione depletion. J Cell Biol 139:1317-1324.

Li Y, Maher P, Schubert D (1997b) A role of 12-lipoxygenase in nerve cell death caused by glutathione depletion. Neuron 19:453-463.

Ma XL, Kumar S, Gao F, Louden CS, Lopez BL, Christopher TA, Wang C, Lee JC, Feuertein GZ, Yue T-L (1999) Inhibition of p38 mitogenactivated protein kinase decreases cardiomyocyte apoptosis and improves cardiac function after myocardial ischemia and reperfusion. Circulation 99:1685-1691.

Mackay K, Mochly-Rosen D (1998) An inhibitor of p38 mitogenactivated protein kinase protects neonatal cardiac myocytes from ischemia. J Biol Chem 274:6272-6279.

Maher P, Davis JB (1996) The role of monoamine metabolism in oxidative glutamate toxicity. J Neurosci 16:6394-6401.

McAdoo DJ, Xu G-Y, Robak G, Hughes MG (1999) Changes in amino acid concentrations over time and space around an impact injury and their diffusion through the rat spinal cord. Exp Neurol 159:538-544.

McClellan M, Kievit P, Auersperg N, Rodland K (1999) Regulation of proliferation and apoptosis by epidermal growth factor and protein kinase $\mathrm{C}$ in human ovarian surface epithelial cells. Exp Cell Res 246:471-479

Misra-Press A, Rim CS, Yao H, Roberson MS, Stork PJS (1995) A novel mitogen-activated protein kinase phosphatase. $J$ Biol Chem 270:14587-14596.

Mochly-Rosen D, Kauvar M (1998) Modulating protein kinase C signal transduction. Adv Neurol 44:91-145.

Morimoto BH, Koshland DE (1990) Induction and expression of long and short term neurosecretory potentiation in a neural cell line. Neuron 5:875-880

Murphy TH, Miyamoto M, Sastre A, Schnaar RL, Coyle JT (1989) Glutamate toxicity in a neuronal cell line involves inhibition of cystine transport leading to oxidative stress. Neuron 2:1547-1558.

Murray B, Alessandrini A, Cole AJ, Yee AG, Furshpan EJ (1998) Inhibition of the p44/42 MAP kinase pathway protects hippocampal neurons in a cell-culture model of seizure activity. Proc Natl Acad Sci USA 95:11975-11980.

Murray MR, Fields AP (1997) Atypical protein kinase C $\lambda$ protects human leukemia cells against drug-induced apoptosis. J Biol Chem 272:27521-27524.

Newcomb R, Sun X, Taylor L, Curthoy N, Giffard RG (1997) Increased production of extracellular glutamate by the mitochondrial glutaminase following neuronal death. J Biol Chem 272:11276-11282.

Nishizuka Y (1995) Protein kinase C and lipid signaling for sustained cellular responses. FASEB J 9:484-496.

Okumura K, Shirasawa S, Nishioka M, Sasazuki T (1999) Activated Ki-Ras suppresses 12-0-tetradecanoylphorbol-13-acetate-induced activation of the c-Jun NH2-terminal kinase pathway in human colon cancer cells. Cancer Res 59:2445-2450.

Olney JW (1969) Brain lesions, obesity and other disturbances in mice treated with monosodium glutamate. Science 164:719-721.

Roulston A, Reinhard C, Amiri P, Williams LT (1998) Early activation of c-Jun N-terminal kinase and p38 kinase regulate cell survival in response to tumor necrosis factor $\alpha$. J Biol Chem 273:10232-10239.

Rubin LL (1997) Neuronal cell death: when, why and how. Br Med Bull 53:617-631.

Sagara Y, Schubert D (1998) The activation of metabotropic glutamate receptors protects nerve cells from oxidative stress. J Neurosci 18:6662-6671.

Sanna MG, Duckett CS, Richter BWM, Thompson CB, Ulevitch RJ (1998) Selective activation of JNK1 is necessary for the anti-apoptotic activity of hILP. Proc Natl Acad Sci USA 98:6015-6020.

Satoh T, Nakatsuka D, Watanabe Y, Nagata I, Kikuchi H, Namura S (2000) Neuroprotection by MAPK/ERK kinase inhibition with U0126 against oxidative stress in a mouse neuronal cell line and rat primary cultured cortical neurons. Neurosci Lett 288:163-166.

Schulz JB, Lindenau J, Seyfried J, Dichgans J (2000) Glutathione, oxidative stress and neurodegeneration. Eur J Biochem 267:4904-4911.

Sebolt-Leopold JS, Dudley DT, Herrera R, Van Becelaere K, Wiland A Gowan RC, Tecle H, Barrett SD, Bridges A, Przybranowski S, Leopold WR, Saltiel AR (1999) Blockade of the MAP kinase pathway suppresses growth of colon tumors in vivo. Nat Med 5:810-816.

Singer CA, Figueroa-Masot A, Batchelor RH, Dorsa DM (1999) The mitogen-activated protein kinase pathway mediates estrogen neuropro- 
tection after glutamate toxicity in primary cortical neurons. J Neurosci 19:2455-2463.

Stadheim TA, Kucera GL (1998) Extracellular signal-regulated kinase (ERK) activity is required for TPA-mediated inhibition of druginduced apoptosis. Biochem Biophys Res Commun 245:266-271.

Stanciu M, Wang Y, Kentor R, Burke N, Watkins S, Kress G, Reynolds I, Klann E, Angiolieri MR, Johnson JW, DeFranco DB (2000) Persistent activation of ERK contributes to glutamate-induced oxidative toxicity in a neuronal cell line and primary neuron cultures. J Biol Chem 275:12200-12206.

Szallasi Z, Smith CB, Pettet GR, Blumberg PM (1994) Differential regulation of protein kinase $\mathrm{C}$ isozymes by bryostatin 1 and phorbol 12-myristate 13-acetate in NIH $3 \mathrm{T3}$ fibroblasts. J Biol Chem 269:2118-2124.

Tan S, Sagara Y, Liu Y, Maher P, Schubert D (1998a) The regulation of reactive oxygen species production during programmed cell death. J Cell Biol 141:1423-1432.

Tan S, Wood M, Maher P (1998b) Oxidative stress in nerve cells induces a form of cell death with characteristics of both apoptosis and necrosis. J Neurochem 71:95-105.

Tanoue T, Moriguchi T, Nishida E (1999) Molecular cloning and characterization of a novel dual specificity phosphatase, MKP-5. J Biol Chem 274:19949-19956.

Tsuchida M, Manthei ER, Alam T, Knechtle SJ, Hamawy MM (2000) Regulation of $\mathrm{T}$ cell receptor- and CD28-induced tyrosine phosphorylation of the focal adhesion tyrosine kinases Pyk 2 and Fak by protein kinase C. A role for protein tyrosine phosphatases. J Biol Chem 275:1344-1350.

Wang X, Martindale JL, Liu Y, Holbrook NJ (1998) The cellular response to oxidative stress: influences of mitogen-activated protein kinase signalling pathways on cell survival. Biochem J 333:291-300.

Whelan RDH, Parker PJ (1998) Loss of protein kinase C function induces an apoptotic response. Oncogene 16:1939-1944.

Wilkinson SE, Parker PJ, Nixon JS (1993) Isoenzyme specificity of bisindolylmaleimides, selective inhibitors of protein kinase C. Biochem J 294:335-337.

Winter C, Schenkel J, Zimmermann M, Herdegen T (1998) MAP kinase phosphatase 1 is expressed and enhanced by FK506 in surviving mammillary, but not degenerating nigral neurons following axotomy. Brain Res 801:198-205.

Xia Z, Dickens M, Raingeaud J, Davis RJ, Greenberg ME (1995) Opposing effects of ERK and JNK-p38 MAP kinases on apoptosis. Science 270:1326-1331.

Zeidman R, Pettersson L, Sailaja PR, Truedsson E, Fagerstrom S, Pahlman S, Larsson C (1999) Novel and classical protein kinase C isoforms have different functions in proliferation, survival and differentiation of neuroblastoma cells. Int J Cancer 81:494-501.

Zhang Y, Huang Y, Rishi AK, Sheikh MS, Shroot B, Reichert U, Dawson M, Poirer G, Fontana A (1999) Activation of the p38 and JNK/SAPK mitogen-activated protein kinase pathways during apoptosis is mediated by a novel retinoid. Exp Cell Res 247:233-240. 